\title{
咽喉頭異常感を主訴とした脳幹腫瘍例
}

\author{
松村 優子 ・田部 哲也・唐帆 健浩 \\ 大前由紀雄* $\cdot$ 北原 哲
}

\section{A Case of Brainstem Tumor with the Onset of Abnormal Sensations in the Throat}

\author{
Yuko Matsumura, Tetsuya Tanabe, Takehiro Karaho and Satoshi Kitahara \\ (National Defense Medical College) \\ Yukio Omae \\ (Tokyo Metropolitan Geriatric Hospital)
}

\begin{abstract}
A-23-year-old man complained of abnormal sensations in his throat and dysphagia for 4 months. $\mathrm{He}$ had a variety of other complaints such as general fatigue, anorexia, nausea, and vomiting. $\mathrm{He}$ was diagnosed with dysautonomia, but the complaints persisted. He consulted our clinic on Dec. 2, 1996. Videofluoroscopic findings showed aspiration, retention of barium in valleculae and pyriform sinuses, and an incomplete opening of the upper esophageal sphincter (UES). Manometric findings revealed abnormal relaxation of the UES, low pharyngeal pressures during pharyngeal contraction, and simultaneous contractions of the pharynx, which suggested a swallowing disorder. MRI revealed the existence of a brainstem tumor. Videofluoroscopy and manometry were useful for objectively assessing the abnormal sensations in his throat and dysphagia.
\end{abstract}

Key words : brainstem tumor, dysphagia, dysautonomia, videofluoroscopy, manometry

はじめに

咽喉頭異常感を訴える患者が, ほかにも自律神経失調 症状を思わせる多彩な訴えを有するとき，器質的疾患を 除外した上で, 自律神経失調による不定愁訴としての咽 喉頭異常感症と診断されることがある.

自律神経失調症とは, さまざまな身体的自律神経失調 性愁訴を有し, 諸種検查で除外診断が行われた上で, 器 質的疾患の見い出されない機能的疾患群と定義されてい る1). 原因となる障害部位は多岐にわたるため, 各臟器 別に機能検査を行い，結果を総合して診断しなければな らない2).

今回, 咽喉頭異常感をはじめとした多彩な症状から，
当初自律神経失調症掞よび咽喉頭異常感症として対処さ れていた脳幹部腫瘍の 1 症例を経験したので報告する.

症例 : 23 歳, 男性.

主訴 : 咽喉頭異常感, 臙下困難感.

現病歴: 1996年 8 月頃より主訴が出現し, 近医で胃炎 の診断にて投薬を受けるる症状不変であった．9月頃よ り, 手指, 足先のしびれ感も出現したため, 某病院神経 内科を受診し, 自律神経失調症の診断で経過観察されて いた．その後も症状が続くため，11月22日当院内科を受 診し, 血液検査, 神経学的所見等に異常を認めず, 咽喉 


\section{表 1 初診時の自覚症状}

・身体が非常にだるくて1日中寝てばかりいる.

・食物を飲んだり食べたりすると，のどにつまる感じで嘔吐 してしまう。

・吐き気がして気持らが德く，嘔吐することが多い，

・食欲が全くない。

・1 日に, ティッシュを 1 箱から 2 箱使うほど, 頻繁に痰 がからんできれない。

・声がかれてでないので，話すことがつらい。

・手足の先が冷たくて，血行が悪い.

・手足の先がしびれていて字が書けない。

・立ちくらみがひどく, 歩いていても, 倒れてしまう。

・後頭部の付恨が痛む.

・いらいらして怒りっぽい。

頭領域の精査のため 12 月 2 日当科を紹介受診した.

現症括よび検査所見: 初診時には多彩な自覚症状を訴 光ていた(表 1 ). 咽喉頭領域に明らかな器質的異常を認 めなかったが, 咽頭反射の消失と, 両側梨状陷凹の著明 な唾液貯留を認めた。精査のため, 咽頭食道造影検査を
施行した。

咽頭食道透視画像の正面二重造影像（図 1 a) では，喉 頭蓋谷と両側梨状陷凹に造影剤の残存貯留を認め, 咽頭 クリアランス能の著明な低下を示した。側面充盈像(図 1 b) では，食道入口部開大不良と下降期型誤嬹を認め た。また，食道蠕動運動の低下を認めた。しかし器質的 異常は認めず，これらの所見から機能的嚥下障害を考光， 嬹下圧検查も施行した。

舌根, 喉頭蓋谷, 下咽頭, 食道入口部の各部位の興下 圧を同時に測定し，嚥下圧波形を $50 \mathrm{~mm} /$ 秒で記録し た3). 図 2 に, 本症例, 特よび比較のために同検査を施 行した対照群の健常成人ボランティア 8 例のうち 1 例の 嚥下圧波形 ( 1 回嚥下量は $140 \%$ 硫酸バリウム $5 \mathrm{ml}$ ) を示

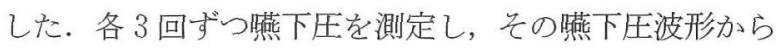
食道入口部弛緩開始時を基準として，各部位の最大嚥下 圧波ピーク出現時を測定し，分散分析にて対照例 8 例と 本症例を比較検討した（図 3 ). 各部位の最大嬩下王波の ピークが対照例では順次出現しているのに対して, 本症 例ではほぼ同時に出現して㧊り，與下時の咽頭収縮生の

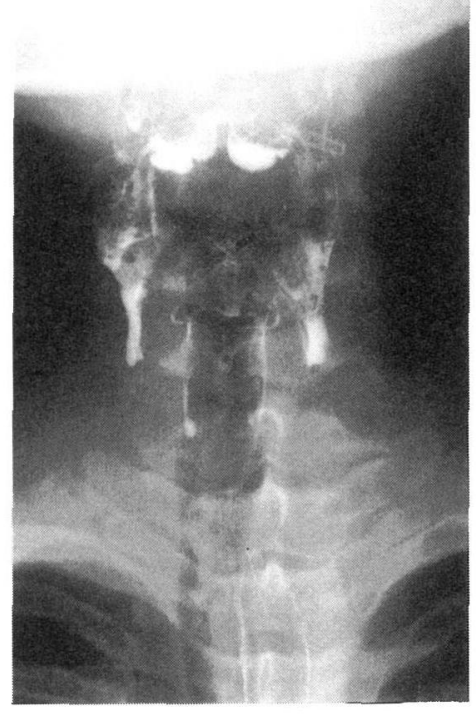

a

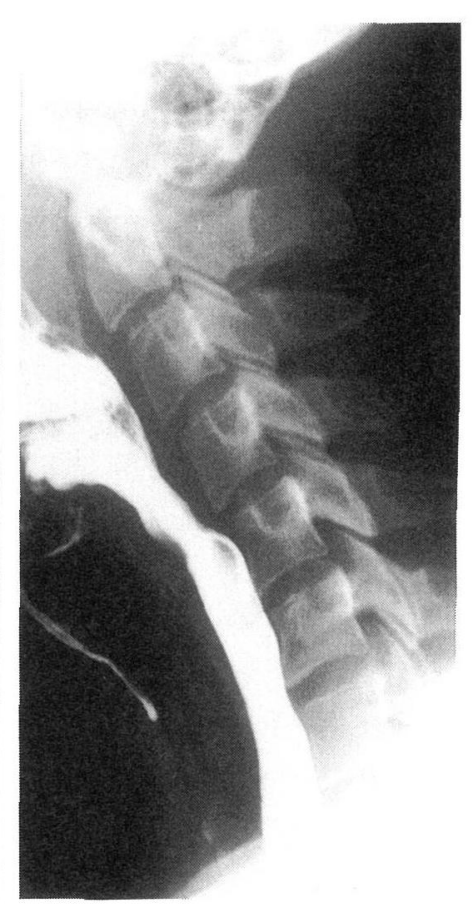

b

図 1 咽頭食道透視画像

a . 正面二重造影像. 咽頭クリアランス能の著明な低下を認めた.

b. 側面充盈像. 食道入口部開大不良と下降期型誤燕孛認めた. 


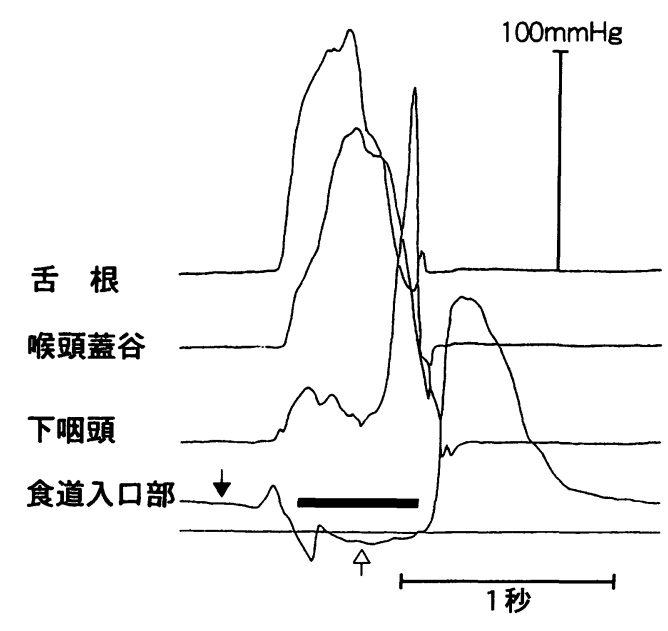

対照例

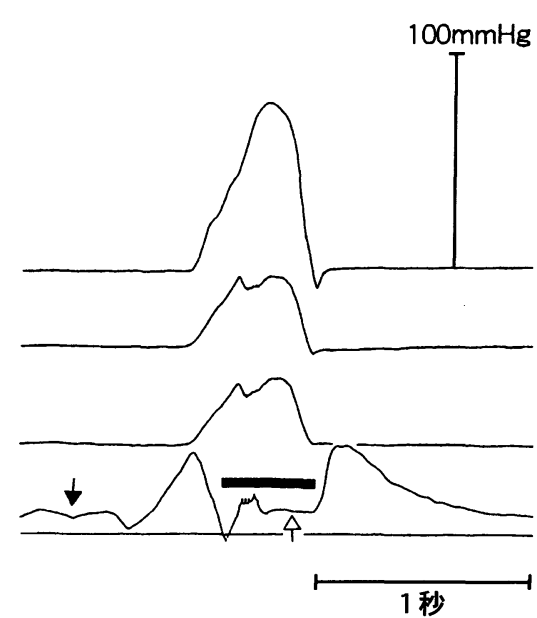

本症例

図 2 燕下圧波形

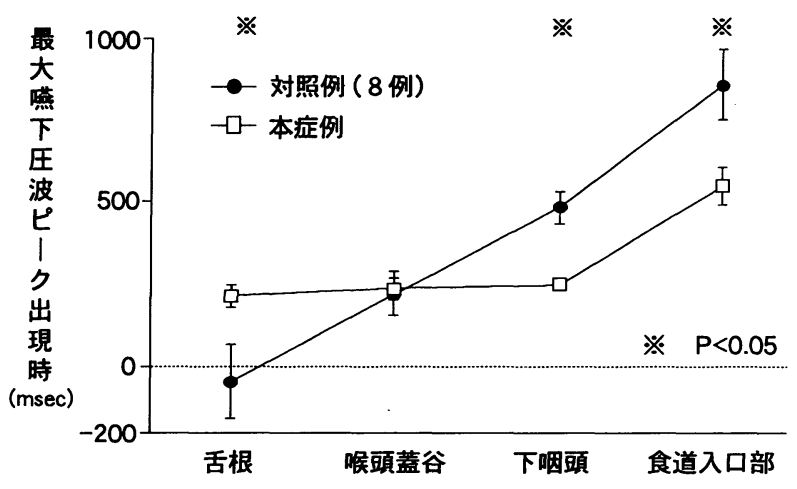

図 3 食道入口部弛緩開始時を基準としたときの最大燕下圧波 ピーク出現時

\section{伝搬異常が示唆された4).}

図 4 に各部位の最大嚥下王値, 図 5 に食道入口部の弛 緩時間と弛緩圧值の結果をグラフで示した. 最大嚥下圧 值は, すべての部位で本症例が対照例より低く, 咽頭収 縮力 ${ }^{4)}$ の低下が示唆された. また, 本症例の食道入口部 の弛緩時間は対照例より有意に短く, 弛緩圧は対照例よ り有意に高值であり，食道入口部弛緩不全が考えられた。 経過 : 以上の検査結果より, 咽頭期に和ける機能的嚥 下障害を呈する疾患の存在を疑い中枢性疾患の検索とし て, 頭部 CT 検査を施行したが明らかな異常所見を認め なかった．MRI 検査を予定して内科と併診で経過観察
していたところ，10日後に歩行困難が出現した.このと き, 四肢筋力, 緊張共に正常で, 筋萎縮, 小脳失調症状 等も認めず, 異常所見として左方注視眼振が認められた.

その 2 週間後, さらに左右注視方向性眼振, 舌右方偏 位，右下腿振動覚低下，両側腱反射元進，ロンベルグ陽 性, 構音障害, 膀脱直腸障害が出現し, 下位脳神経障害, 脳幹および後索障害が強く嶷われた。

12月27日に施行した頭部 MRI 検査で, 延髄から頸髄 接合部にかけて, T1 強調画像で低信号, T2 強調画像 で高信号を示し，ガドリニウムで周囲を強くエンハンス される内部不均一で辺縁不整な髄内性腫瘍を認めた(図 6 ). 脳幹部腫瘍の診断で, 1997年 1 月 16 日当院脳神経 外科にて開頭腫瘍切除術による後頭蓋窩減圧術を行った. 病理組織診断は未分化型星状細胞腫であった. 術後, 二 トロソウレア系薬剤, インターフェロンー $\beta$ 扎よび放射 線併用療法が施行されたが著効なく，同年11月呼吸不全 にて死亡した.

\section{考察}

自律神経機能の検査法は, (1)愁訴による方法, (2)理学 的方法, (3)薬理学的方法, (4)生化学的方法, (5)電気生理 学的方法などがあり5), このうち愁訴による方法では, 阿部ら1) がューネルメディカルインデックスから自律神 経失調症状に関係が深いとして選んだ43項目が, 問診に 

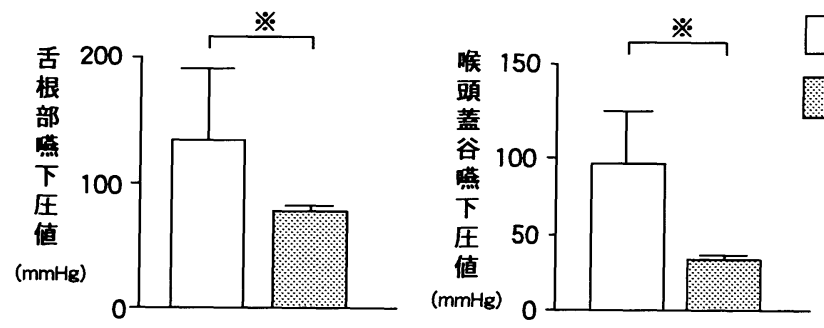

\section{対照例 ( 8 例)}

本症例
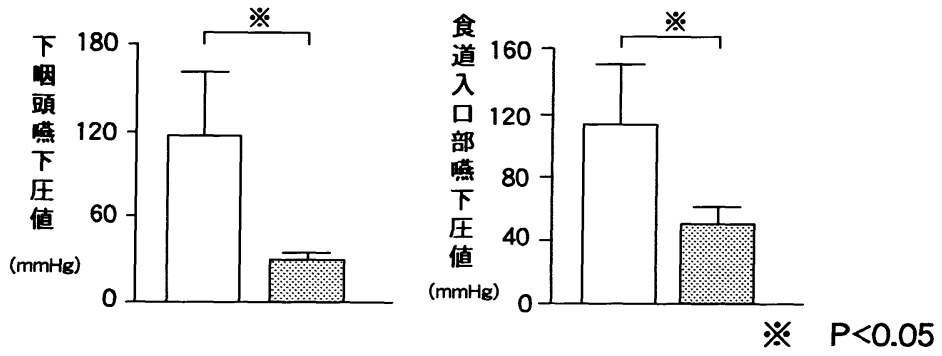

図 4 最大嚥下圧値

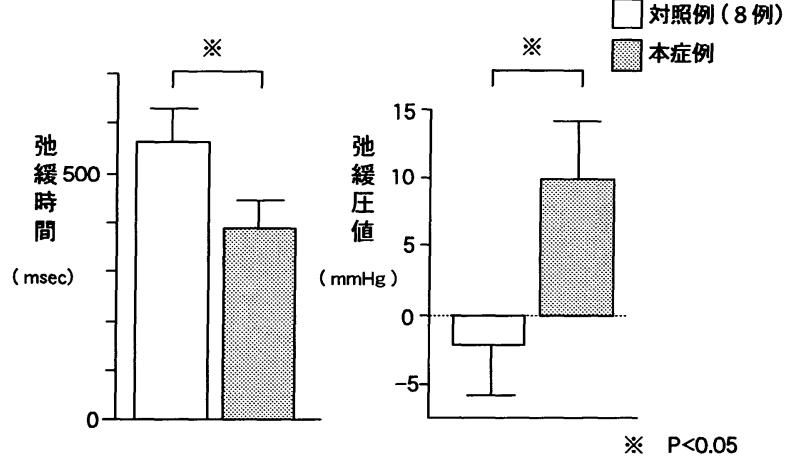

図 5 食道入口部弛緩時間と弛緩圧値

用いられることがある. 本症例の自覚症状(表 1 )の11項 目のらち8項目がこれにあてはまった．このように自律 神経失調症状を思わせる症状が多彩で, かつ自覚症状を 認めた初期の段階での諸検査で, 器質的疾患を示唆する 所見を認めなかったことより，自律神経失調症状による 不定愁訴として対処され, 咽喉頭異常感 - 嚥下困難感に 対しても，いわゆる咽喉頭異常感症として対処された可 能性は否定できない。

当科では咽喉頭異常感を主訴とする患者に対し, 問診 や耳鼻咽嗼科領域の視診を行った上で, 検査に同意を得 たものについては咽頭食道造影検査を施行し，さらなる 検索が必要と考兄た場合は，燕下圧検査を施行している. 本症例は耳鼻咽喉頭領域に器質的異常を認めなかったが,
咽喉頭視診所見にて，嘔吐反射の消失や，梨状窩への唾 液貯留などの所見を認め, さらに咽頭食道造影検查扣よ び燕下圧検查から, 燕下時咽頭収縮波の伝搬異常, 咽頭 収縮力の低下, 食道入口部驰緩不全所見などを認めたた め機能的與下障害を呈する疾患の存在を疑い得た．この ことから, 咽喉頭異常感を訴兄る患者に対する器質的お よび機能的異常を検索する上で, 咽頭食道造影検査は有 用であると考光た．また，燕下圧の測定値を対照例と比 較することで，燕下障害について詳細かつ客観的な検討 が可能であり，臨床診断に有益な情報を得ることができ ると考穴た。

画像診断に扣いて，骨によるアーチファクトの影響を 受けるCTよりも，骨の影響を受けず矢状断像が得られ る MRI の方が, 側頭骨, 後頭骨, 蝶形骨に囲まれた後 頭蓋窩病変の診断に優れる67). 本症例も CT では明ら かでないが，MRIでは腫瘍陰影が鮮明に描出されて拉 $\eta$, 後頭蓋窩領域である脳幹部の画像診断には, 診察当 初より MRI 検査を予定すべきと反省させられた。

進ら ${ }^{8)}$ は, 咽喉頭知覚からの入力が, 孤束核内の二ュロンに収束された後, 延葡網様体内にあるニューロンに 伝兄れ, 入力が一定の閾值に達すると, 燕下のパタ一 ン形成器が活性化され, パターン出力のプログラムに従 い, 疑核内の二ューロンが順次駆動され, 反射性に一連 の咽喉頭共同運動(咽頭期嚥下)が若起されるとしている. 森9) は, 燕下時咽頭収縮圧の伝搬異常は, この燕下中枢 


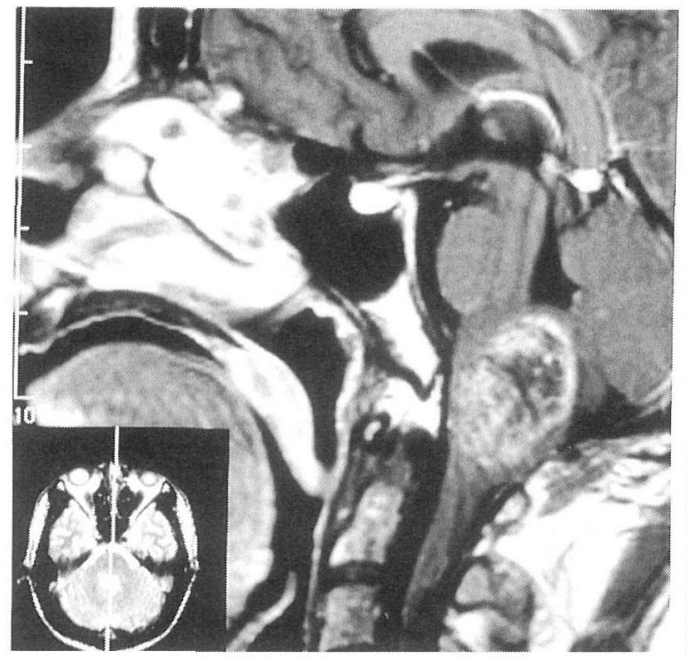

a

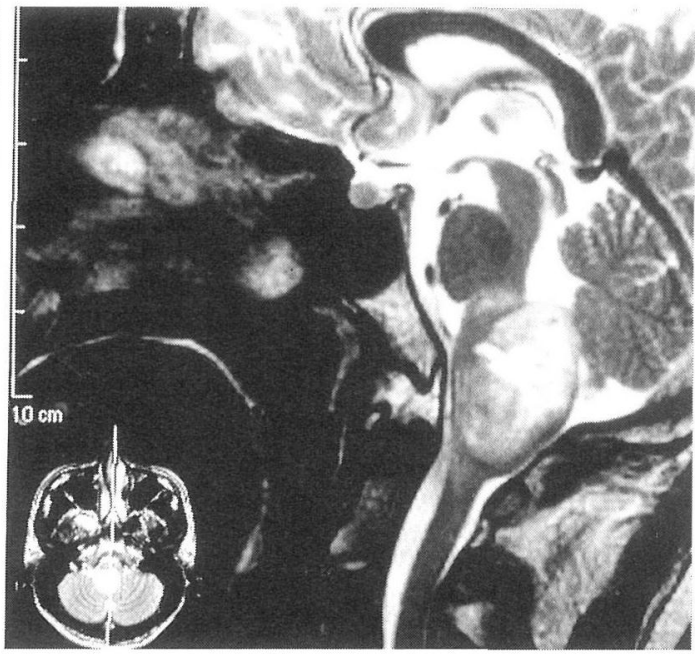

b

図 6 頭部 MRI 画像

a. T1 ガドリニウム強調画像. b. T 2 強調画像. 延髄から頸髄接合部にかけて, T1 強調画像で 低信号，T2 強調画像で高信号を示し，周囲をガドリニウムで強くエンハンスされる，内部不均一 で辺縁不整な $2.7 \times 2.5 \times 4.3 \mathrm{~cm}$ の䯣内性腫瘍を認めた。

に括けるパターン出力のプログラムが障害された結果生 じた興下関与筋の活動時期の異常によるとしている. 本 症例は, 咽喉頭異常感や嘔気を訴光, 咽頭刺激による嘔 気も自覚したが嘔吐反射は認めずまた咽頭期に和ける 薑下障害を認めたことから, 咽喉頭知覚の求心路機能は 残存していたが，中枢から出力に至るまでの経路が腫瘍 により主に障害され，パターン出力のプログラム障害が 生じ，鱟下時咽頭収縮圧の伝搬異常や咽頭収縮圧の低下 を呈したと考光た。この時点での障害部位は, 嘔吐中枢 の存在する延䯑道網様体外背側部 ${ }^{10)}$, 食道蠕動運動の遠心

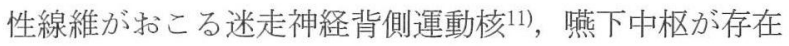
する延髄網様体背側部12)，酀下運動核である疑核などが 想定され, 腫瘍を延䯣中心側飞認めた MRI 画像所見と

一致した。

延髄網様体は, 自律神経調節の最高位中枢である視床 下部11)と連絡してさまざまな自律機能を調節するほか に, 脳神経運動核の運動ニューロンとの間に線維連絡を 持ち, 姿勢を保持する反射と関係があるとされている13). Masdeu ら ${ }^{14)}$ は, 食欲不振呈した延䯣神経膠腫症例の

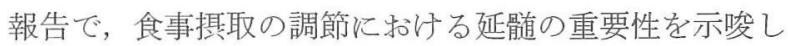
ている. 本症例が当初訴光た多彩な自律神経失調症状は, 自律神経系の調節に重要な役割を果たすこの延䯣網様体 の障害により生じたものと推測された。
さらに, 腫瘍の増大や周囲組織の浮腫により周辺の脳 神経核や後索まで障害が及び, 構音障害, 舌偏位, 眼振, 深部知覚異常, 協調運動障害による歩行困難が出現した と考光た。

$$
\text { まとめ }
$$

1. 咽㮢頭異常感を主訴とした脳幹部腫瘍の 1 症例を 経験した。

2. 神経学的異常所見が顕著となる前に, 咽頭食道造 影検査加ら機能的鱟下障害所見を認め, 中枢性疾患の存 在を疑い得た。

3. 咽喉頭異常感を訴光る症例に対する検査として, 咽頭食道造影検査の有用性を再認識すると共に，燕下圧 検査は照下機能を客観的に評価し，臨床診断に有益な情 報を得ることができると考光た。

本稿を終えるにあたり，御協力を賜りました防衛医科大学校 脳神経外科学講座千, 崎裕夫前教授, 島克司教授, 石原正一郎 先生に深謝致します.

本論文の要旨は, 第59回耳鼻咽喉科臨床学会(1997年 6 月京 都), 第72回日耳鼻埼玉県地方部会(1999年 6 月浦和) に拈いて ロ演した。 


\section{参考文献}

1 ) 阿部達夫, 筒井末春 : 不定愁訴患者の扱い方. 治療 46 : 1253 1261, 1964.

2 ）片山宗一, 浮田和照, 長澤雅和 : 自律神経失調症の診断基 準・病理分類・重症度. 内科 $75: 1409 \sim 1413,1995$.

3 ）大前由紀雄：4 点同時嚥下恰査による嚥下動態の評価. 耳鼻臨床 $86:$ 573〜 583, 1993.

4) McConnel FMS : Analysis of pressure generation and bolus transit during pharyngeal swallowing. Laryngoscope $98: 71 \sim 78,1988$.

5 ) 中野弘一：自律神経機能検査法. 耳鼻咽喉科・頭頸部外科 MOOK（野村恭也編）．129～138頁，金原出版，東京， 1988.

6 ) 根本 裕 : 後頭蓋窩腫瘍. 中枢神経疾患の MR 診断(井上 佑一編). 104 122頁, 金原出版, 東京, 1990 .

7 ）高橋睦正：中枢神経の画像診断. 中枢神経疾患の画像診断 (高橋睦正編). $1 \sim 25$ 頁, 南江堂, 東京, 1989.

8 ）進 武幹, 高木誠治 : 㖟下の中枢制御機構. 日気食会報 49 : 395 404, 1998
9 ）森 敏裕：嚥下第二期に括ける曣下圧動態の研究. 日耳鼻 $95: 1022 \sim 1034,1992$.

10) Herbert L, Borison and Wang SC : Physiology and pharmacology of vomiting. Pharmacol Rev 5 : 193 230, 1953.

11）荒木淑郎：感覚と自律系. 自律神経疾患 基礎と臨床(宇 尾野公義編). 47 51頁，金原出版，東京， 1992.

12) Doty RW, Richmond WH and Storey AT : Effect of medullary lesions on coordination of deglutition. Exp Neurol $17: 91 \sim 106,1967$.

13）伊藤 隆 : 中枢神経系. 解剖学講義(発行者 鈴木正二). 647 770頁, 南山堂, 東京, 1986.

14) Masdeu JC and Ross ER : Medullary satiery. Neurology 38 : 1643 1645, 1988.

$\left(\begin{array}{l}\text { 原稿受付 : 平成 } 12 \text { 年 } 2 \text { 月 } 28 \text { 日 } \\ \text { 原稿採択 : 平成 } 12 \text { 年 } 4 \text { 月 } 12 \text { 日 } \\ \text { 別刷請求先 : 松村優子 } \\ \text { 干 } 359-8513 \text { 所沢市並木 } 3-2 \\ \text { 防衛医科大学校耳鼻咽喉科学講座 }\end{array}\right)$

